\title{
Correction to: Suitable methods for isolation, culture, storage and identification of wheat blast fungus Magnaporthe oryzae Triticum pathotype
}

Dipali Rani Gupta ${ }^{1 \dagger}$, Musrat Zahan Surovy $^{1 \dagger}$, Nur Uddin Mahmud ${ }^{1 \dagger}$, Moutoshi Chakraborty $^{1}$, Sanjoy Kumar Paul ${ }^{1}$, Md. Shaid Hossain', Pallab Bhattacharjee', Md. Shabab Mehebub', Kanistha Rani', Rumana Yeasmin', Mahfuzur Rahman ${ }^{2}$ and Md Tofazzal Islam ${ }^{1 *}$

Correction to: Phytopathol Res 2, 30 (2020) https://doi.org/10.1186/s42483-020-00070-x

In the original publication of this article (Gupta et al. 2020), the family name of the fourth author is incorrect. The correct family name of this author should be Chakraborty rather than Chakrabarty. The original publication has been corrected.

\section{Author details}

'Institute of Biotechnology and Genetic Engineering, Bangabandhu Sheikh Mujibur Rahman Agricultural University, Gazipur 1706, Bangladesh. ${ }^{2}$ Extension Service, Davis College of Agriculture, West Virginia University, Morgantown, USA.

Published online: 22 September 2020

\section{Reference}

Gupta, et al. Suitable methods for isolation, culture, storage and identification of wheat blast fungus Magnaporthe oryzae Triticum pathotype. Phytopathol Res. 2020;2:30. https://doi.org/10.1186/s42483-020-00070-x.

The original article can be found online at https://doi.org/10.1186/s42483020-00070-x

* Correspondence: tofazzalislam@yahoo.com

${ }^{\dagger}$ Dipali Rani Gupta, Musrat Zahan Surovy and Nur Uddin Mahmud contributed equally to this work.

${ }^{1}$ Institute of Biotechnology and Genetic Engineering, Bangabandhu Sheikh

Mujibur Rahman Agricultural University, Gazipur 1706, Bangladesh

Full list of author information is available at the end of the article

(c) The Author(s). 2020 Open Access This article is licensed under a Creative Commons Attribution 4.0 International License, which permits use, sharing, adaptation, distribution and reproduction in any medium or format, as long as you give appropriate credit to the original author(s) and the source, provide a link to the Creative Commons licence, and indicate if changes were made. The images or other third party material in this article are included in the article's Creative Commons licence, unless indicated otherwise in a credit line to the material. If material is not included in the article's Creative Commons licence and your intended use is not permitted by statutory regulation or exceeds the permitted use, you will need to obtain permission directly from the copyright holder. To view a copy of this licence, visit http://creativecommons.org/licenses/by/4.0/. 